This item was submitted to Loughborough's Research Repository by the author.

Items in Figshare are protected by copyright, with all rights reserved, unless otherwise indicated.

\title{
Repackaging national identity: Cool Japan and the resilience of Japanese identity narratives
}

PLEASE CITE THE PUBLISHED VERSION

https://doi.org/10.1080/02185377.2019.1594323

\section{PUBLISHER}

(C) Informa UK Limited, trading as Taylor \& Francis Group

\section{VERSION}

AM (Accepted Manuscript)

\section{PUBLISHER STATEMENT}

This is an Accepted Manuscript of an article published by Taylor \& Francis in Asian Journal of Political Science on 9 Mar 2019, available online: https://doi.org/10.1080/02185377.2019.1594323

\section{LICENCE}

CC BY-NC-ND 4.0

\section{REPOSITORY RECORD}

Tamaki, Taku. 2019. "Repackaging National Identity: Cool Japan and the Resilience of Japanese Identity Narratives”. figshare. https://hdl.handle.net/2134/37262. 


\title{
Repackaging National Identity: Cool Japan and the Resilience of Japanese Identity Narratives
}

\begin{abstract}
Cool Japan' is an instance of Japanese government's nation branding exercise as part of its soft power projection in which the unique selling point is identified as Japanese national identity. In this paper, I examine the relationship between Cool Japan and Japanese national identity and highlight a tension in the construction. Cool Japan is about emphasizing Japan's attractiveness for public diplomacy, while the top-down nature of the branding undermines the imagery that the branding is designed to convey. I show that policy elites resolve this tension by invoking the traditional Japanese identity narratives that construct Japan into both a non-Western and an un-Asian entity, reproducing the myth of Japanese uniqueness. I argue that the elite narratives surrounding Cool Japan readily replicate the language reminiscent of prewar identity construction. Despite the contemporary popularity of manga and anime, the purported 'coolness' of these products are framed within older constructions of Japanese Self that can trace their pedigree back to the 19th century. Using the minutes of committee meetings, policy documents, as well as media interviews given by policy- and business elites, I show that Cool Japan is effectively a $21^{\text {st }}$ century rendition of the familiar Japanese identity construction.
\end{abstract}

Key Words: Japan; Cool Japan; National Identity; Nation Branding; Public Diplomacy

Japan prides itself on the international appeal of its cultural- and hi-tech products. The Japanese government and businesses exude confidence in how Japanese products such as manga (cartoons), anime (animation), hi-tech gadgets, and traditional Japanese cuisine and hospitality enhance Japan's international image and soft power. Ever since tourism has been promoted as a diplomatic tool during the Koizumi administration, the Japanese government has sought to capitalize on the favourable international images enjoyed by Japanese consumer products. One of the tangible 
outcomes of this process has been the Cool Japan Initiative and 'Cool Japan' as a catchphrase, a government-led project at attracting inbound tourists to boost Japanese economy, particularly following the March 2011 disasters (hereafter 3/11).

How do the official narratives of Cool Japan represent Japanese collective identity? Are there similarities with the prewar identity narratives? On the one hand, Cool Japan is a government programme for 'packaging' purported Japaneseness for international consumption. On the other hand, we can witness the residues of a familiar identity representation: that Japan is non-Western and un-Asian; and hence Japan is essentially unique. The international popularity of manga and anime is a contemporary phenomenon, but the official narratives reveal that the alleged 'coolness' of these products is framed within the older constructions of Japanese Self that can trace their pedigree back to the $19^{\text {th }}$ century. In short, Cool Japan is a $21^{\text {st }}$ century rendition of the myth of Japanese uniqueness.

The recourse to traditional identity construction is due to the vagueness of Cool Japan: the official deliberations show that officials, advisors, and commentators themselves struggle to define the catchphrase. As a result, Cool Japan narratives default to the traditional identity construction, adding another layer to the pre-existing identity framework. The implications for political science are significant: because nation branding encompasses both public diplomacy and identity entrepreneurship by governments, Cool Japan as a vehicle for public diplomacy reveals the efficacy—or otherwise - of top-down nation branding exercise.

This article analyzes the elite narratives of Cool Japan gleaned from published minutes of committee meetings, official documents and publications, media interviews given by policy elites, as well as ideas shared by prominent people in business and showbusiness to explore the narrative framework surrounding Cool 
Japan. While the focus of existing literature centres on Cool Japan's impact on the contents industry and Japanese pop culture, this article takes a step back and concentrates on the narrative constructions. The aim is to determine how the Cool Japan narratives are constructed and where they sit in respect of the historical reconstruction of Japaneseness. The narratives reveal that the Japanese government lacks a clear definition of Cool Japan: it remains a convenient catchphrase to denote Japanese uniqueness, however construed. On the one hand, the government officials seem relaxed about this lack of precision, being primarily concerned with revitalizing the economy. On the other hand, government advisors and commentators find the process of defining Cool Japan to be frustrating, reverting to the familiar identity construction dating back to the late- $19^{\text {th }}$ century: that Japan is distinct from both the West and Asia, and thus essentially unique. In short, the narrative construction of Japaneseness within the Cool Japan project is predicated on a framework established more than a century ago.

This article is divided into four sections. The first section reviews the literature on nation branding and Cool Japan. Here, we see that nation branding is about packaging national identity, and Cool Japan is a convenient catchphrase to emphasize the purported Japaneseness of the products being promoted. However, there is a scope for further exploring the historical pedigree of identity construction within Cool Japan narratives. The second section then provides an overview of an idea that depicted Japan as a unique brand on both sides of August 1945 as a way to fathom the differences as well as the seeming continuities in the basic framework. Here, we can discern a sense of continuity in the way the myth of Japanese uniqueness remains at the core of national identity narratives. The third section explores the challenges of Cool Japan. As a government-led exercise in commoditizing purported Japaneseness, 
official narratives lack a clear definition The final section suggests that Cool Japan's lack of definition means that the identity construction defaults to the familiar dual Otherness involving Japan that is neither Western nor Asian, and hence a unique entity. While the components of Cool Japan are contemporary, the ready recourse to the familiar national identity narratives suggests that the promotion of Japan brand is effectively another iteration in the rearticulation of the so-called myth of Japanese uniqueness.

\section{Public Diplomacy, Nation Branding, and National Identity}

There is an organic linkage between public diplomacy, nation branding, and national identity, as they all coalesce around the idea of 'packaging' a positive image of the state in an attempt at nurturing an amicable international environment. Governments pursuing public diplomacy consider nation branding as integral to their national interests. According to Joseph Nye (2008, p. 95), public diplomacy is '[a]n instrument that governments use to mobilize [cultural and socio-economic attributes] to communicate with and attract the publics of other countries'. Nicholas Cull (2008, p. 31) adds that public diplomacy is 'the process by which international actors seek to accomplish the goals of their foreign policy by engaging with foreign publics', with Yoshimoto Hideko (2013, p. 29) suggesting that public diplomacy is about utilizing PR professionals to package a positive image of the state to sell to the outside world. Candace White and Danijela Radic (2014, p. 459) note that '[p]ublic diplomacy is, in effect, a nation-state's international public relations', while Efe Sevin (2015, p. 563; emphasis deleted) argues that, '[p]ublic diplomacy is fundamentally a communication 
tool used by states to reach foreign publics', comprizing 'communication-based activities of states and state-sanctioned actors aimed at non-state groups in other countries with the expectation of achieving foreign policy goals and objectives' (Sevin, 2015, p. 563).

This idea of packaging the state's attractiveness leads to 'nation branding'. According to Simon Anholt (2011, p. 6), 'the reputations of countries ... behave rather like the brand images of companies and products, and they are equally critical to the progress, prosperity, and good management of those places'. He suggests that nation branding is integral to public diplomacy, claiming that, 'good products, services, cultures, tourism, investments, technology, education, business, people, policies, initiatives, and events produced by a good country ... acquire a positive brand image, which eventually reflects on the country, and perhaps also becomes its principle asset' (Anholt, 2011, p. 7). Anholt (2007, p. 14) notes that 'public diplomacy has a chance of ... ensuring that future policy decisions are received in a more favourable light'.

Anholt (2011, p. 8) emphasizes nation branding's affinity to national identity representation, arguing that 'national image has more to do with national identity and the politics and economics of competitiveness than with branding as it is usually understood in the commercial sector'. For Keith Dinnie (2016, p. 4; emphasis deleted), nation brand is 'the unique, multidimensional blend of elements that provide the nation with culturally grounded differentiation and relevance for all of its target audience', adding that, '[n]ations are making increasingly conscious efforts to hone their country branding in recognition of the need to fulfil nationally important objectives in terms of trade, investment and tourism' (Dinnie, 2016, p. 6). Hence, 
nation branding is both a diplomatic charm offensive, as well as a fiscal tool to improve balance of payments.

Nation branding is intricately linked to public diplomacy - they are both about yielding soft power through story-telling involving identity narratives to enhance states' international reputation. In short, nation branding is about utilizing identity narratives in public diplomacy to further national interests. Maureen Whitebrook (2001, pp. 4-10; 133) argues that identity narratives are tantamount to actors telling stories about who they are and how they position themselves within society with a particular audience in mind. Hence, nation branding is about state actors engaging in identity entrepreneurship by co-opting domestic stakeholders into embracing a story of national identity that can be sold to an international audience (Haslam and Reicher, 2007; Fauchart and Gruber, 2011). The important implication for political science is that nation branding allows us to analyze the role of national identity narratives in public diplomacy and explore how state actors engage in identity entrepreneurship.

(Please insert Table around here)

Numerous analyses of Cool Japan focus on nation branding. Michal DaliotBul (2009, p. 249) suggests that, while 'Japan Brand Strategy' is devized 'as a mechanism for national mobilisation', ambiguity remains, since 'Japan Brand is designed as a tag name for an essential attractiveness common' to anything that can be construed as 'Japanese' (Daliot-Bul, 2009, p. 252). Similarly, Katja Valaskivi (2013, p. 488) argues that 'Cool Japan is a social imaginary that brings together the aims of the Japanese government' in promoting contents industry, as well as the 'various interests of artists and producers'. Yet, the proliferation of committees and 
the involvement of various bureaucracies effectively dilutes the message (Valaskivi, 2013, p. 491-2). Koichi Iwabuchi (2015, p. 423) notes that Cool Japan entails a proliferation of committees, focusing on promoting exports and contents industry, while also claming that there is a sense of 'rely[ing] on a naïve assumption about media culture's capacity to improve Japan's reputation abroad' (Iwabuchi, 2015, p. 426). Ultimately, this leads to 'a certain sense of cultural essence' (Iwabuchi, 2015, p. 128). Likewise, Yoshitaka Mōri (2011) argues that Cool Japan relies on outsourcing contents production overseas, raising doubts as to how genuine Cool Japan can be, when so much of it is produced outside of Japan. Effectively, Cool Japan remains a catchphrase that seeks to emphasize Japan's exoticism (Abel, 2011; Brienza, 2014).

The existing literature also raises interesting points about the national identity narratives inherent within Cool Japan. Iwabuchi (2015, p. 428) is critical of the tendency towards essentialism in the articulation of Japaneseness, while Valaskivi (2013, p. 497-8) points to the hollowness of the essentialist-pull in Cool Japan policy circles. Similarly, Daliot-Bul (2009, p. 253-52) observes Japanese government's tendency to invoke an abstract notion of Japaneseness. My contention is that this essentialism has a historical pedigree dating back to the $19^{\text {th }}$ century, constituting a default position when Cool Japan lacks a clear definition. For the Japanese government, Cool Japan is a public diplomacy exercise in attempting to amalgamate products and services produced by disparate industrial sectors into a coherent whole. As such, Cool Japan as a catchphrase fails to convey a systematic sense of Japaneseness, partly explaining why there is a tendency towards essentialism. Because the undercurrent of traditional identity representation remains potent, essentialism remains the only frame for conceptualizing Cool Japan. 


\section{Japan as a Brand in Historical Perspective}

Japanese nation branding has a historical pedigree if we consider prewar attempts by Japanese leaders to have Japan recognized as a member of civilized states. The dominant elite narratives of Japanese uniqueness since the late $19^{\text {th }}$ century was constructed in opposition to two main 'Others', namely the 'West' and 'Asia'. Maruyama Masao (1961, p. 9) claims that kaikoku (the 'opening') in the 1850s exposed Japan to the relentless struggle for power under Realpolitik reinforcing the idea of Japan as an Asian nation. Simultaneously though, Asia has consistently been constructed as another facet of Otherness in opposition to Japanese Self. As Yamamuro Shinichi (2001, p. vii) argues, Asia has always been Japan's destiny (shukumei), and that for generations of Japanese elites, the task of understanding Asia became tantamount to understanding the outside world, as well as a crucial ingredient in the construction of Japanese Self (Yamamuro, 2001, p. 4).

The Western Otherness derived not just from a geographical signifier, but also from a notion that the West represented enlightenment and violence, while Asia denoted a backward and weak entity devoured by Western colonizers. Meiji Restoration and the subsequent modernization, led to the idea that Japan is un-Asian by virtue of its civilizational attainment. As Hirakawa Sukehiro (1998, p. 33) argues, 'Japan's turn to the West had to be carried out in two separate dimensions': first, to import and assimilate Western ideas; and second, to adapt traditional ways of doing things. As Iriye Akira (1966, p. 19) suggests, the 'West' in this formulation was seen as a civilizational benchmark against which Japan's own level of attainment was to be judged, vis-à-vis, Asia. Hence, adopting Western ways of doing things was 
understood as a viable option by the Meiji Oligarchs intent on maintaining Japanese autonomy, particularly upon witnessing China falling victim to Western imperialism (Banno, 2013, p. 39). Indeed, Japanese elites in the late $19^{\text {th }}$ and early $20^{\text {th }}$ centuries felt compelled to partake in Realpolitik in the guise of pan-Asianism (Okamoto, 1998)

Mega sporting events provide an occasion for packaging national attributes (Horne and Manzenreiter, 2012), and the justifications used to bid for the 1940 Olympics provide an interesting snapshot into how Asia and the West were invoked as Otherness to emphasize Japanese uniqueness. According to Sandra Collins (2007, p. 980), 'the uninterrupted imperial lineage, which marked the $2600^{\text {th }}$ anniversary in 1940, was employed to emphasize Japan's exoticism (mezurashii)', while the image of Tokyo as a thriving metropolis not completely alien to the visiting Westerners was a living embodiment of modern Japan, incorporating traditions indicating Japan's Asian affiliation. As Collins (2006, p. 1130) notes, the Olympics organizers in Tokyo hoped to exploit the "visual puzzle of the old within the new and the West within the East'. She quotes a pamphlet published by the organizers in 1931 describing Japan as 'a visual puzzle of the old within the new and the West within the East.... As a unique nation state that embodies both the East/West and the old/new ... as a rare montage of the old within the new' (Collins 2006, p. 1130). Propaganda notwithstanding, the organizers of Tokyo 1940 exploited an image of Japan as a unique entity. Hence, the prewar representations of Japanese identity entailed packaging a story of 'old versus new' to claim that Japan was an essentially unique entity that was simultaneously non-Western and un-Asian.

Even the defeat in August 1945 and the subsequent shift towards pacifism did not fundamentally alter the manner in which Japanese national identity was represented. Postwar pacifism and the ensuing economic reconstruction became a 
platform upon which the policy elites felt confident that Japan remained distinct from the rest of Asia still undergoing development. A former prime minister, Yoshida Shigeru (1995, p. 112-13), wrote that, given Japan's postwar economic boom, Japan was 'less Asian as it was more Western'; and its role should be to act as an 'honest broker' (nakadachi) and to 'convince' (settoku) newly independent states in Africa and Southeast Asia to be open to foreign direct investment. Another snapshot of an early nation branding exercise can be gleaned from Tokyo's bid to host the 1964 Olympics - a seminal moment to package an idea of postwar Japan to an international audience. The Japanese delegates to the May 1959 Munich IOC session claimed that, 'until now, the Olympic games used to be a flower that blossomed on Western culture. Now, we would like the same flower to grow on Far Eastern culture in order to complete the Olympics movement' - and Japan was best qualified to accomplish this (Ikei, 2012, p. 105). There was a sense that only Japan can truly represent a nonWestern host for the Olympics movement. As Taniguchi Gentarō (1997, p. 42) writes,

Ever since the First Asian Games were held in New Delhi, Japanese athletes exhibited their sporting prowess, resulting in the shared idea that Japan was the most advanced sporting nation in Asia, encouraging it to focus more on catching up with the West. It is not surprising that the Asian sporting community felt that 'Japan is not an Asian country' any more.

The residues of dual Otherness remain even today. Tokyo Organizing Committee of the Olympic and Paralympic Games (TOCOG) $(2013$, p. 6) for the 2020 Olympic campaign invoked similar language, suggesting that Japanese 'culture and tradition 


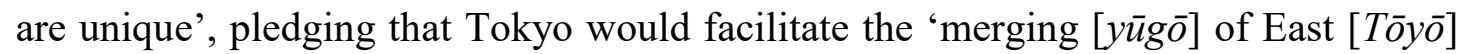
and West $[$ Seiyō]'.

Japan has been involved in a full-fledged public diplomacy since the early 2000s. As Mikami Takanori (2007, p. 15) notes, the Japanese Ministry of Foreign Affairs (MOFA) realized its importance as early as 1957 in its very first issue of the Diplomatic Bluebook. Japanese attention to public diplomacy-and hence the need for better brand management — was exacerbated in the 1960s through a spate of antiJapanese protests in Southeast Asia, reinforcing the purported importance of nurturing positive images of Japan. The Japanese government felt that Japan's postwar goodwill and pacifist intentions needed buttressing, leading to the establishment of Japan Foundation in 1972 (Lee 2015, p. 157). However, public diplomacy as a term only appeared in the 2004 edition of MOFA's Diplomatic Bluebook, when the government recognized the need to spur inward tourism (Mikami, 2007, p. 1), establishing Kōhō bunka kōryū-bu (Public Diplomacy Department) designed as a vehicle for public diplomacy (Lee, 2015, p. 157).

Boosting inward tourism has been one of the prime concerns of the Japanese government. Prime Minister Koizumi Junichirō outlined his intention to increase foreign tourists in January 2003, followed by the implementation of various projects in 2003-4, including the 'Visit Japan Campaign' and 'Youkoso! Japan' programmes, culminating in the establishment of Tourist Agency in October 2008 (Watanabe, 2001, p. 170). Simultaneously, Koizumi realized the importance of branding inspired by Tony Blair's 'Cool Britannia'. Koizumi appointed a former editorial commentator, Takashima Hatsuhisa, as PR spokesperson for MOFA in August 2002 (Nagasawa, 2011, p. 107), who stated that, 'I think the basis of public diplomacy is to try to gain support for the country's diplomatic policies' (Nagasawa, 2011, p. 113). Koizumi 
augmented this by establishing a 'Special Committee on Contents Japan Brand' in early 2003 (Nagasawa, 2011, p. 108), followed by the establishment of a committee on cultural diplomacy (bunka gaikō) in July 2005, as a vehicle for promoting Japanese culture as a '21 ${ }^{\text {st }}$ century cool' (21-seiki-gata küru) (Watanabe, 2001, p. 166). From 2010, the nation branding exercise acquired the moniker of Cool Japan Initiative, encompassing an assortment of attributes that the government felt appealed to international audience, including anime, manga, traditional arts, and washoku (Japanese cuisine).

Despite the seeming rupture of August 1945, Japanese essentialism remains within the dominant narratives of policy elites. Postwar pacifism provides a fertile platform upon which the exercise of Japanese identity representation retains its basic template: Japanese pacifism is an integral element of a brand used to project Japan's non-military power. In his 2006 e-mail newsletter, Koizumi noted that 'it may be that the lifestyle of Japanese people living in peace is drawing the attention of the world rather than military, political, or economic strength' (Valaskivi, 2013, p. 497). As we shall see, Japan that is neither Western nor Asian, and hence something that is unique remains a resilient feature of Japanese identity representation as witnessed through Cool Japan narratives. Essentialism inherent within Cool Japan narratives means that there is nothing new in it: it is effectively a $21^{\text {st }}$ century restatement of the familiar identity construction. The familiar image of a peculiar Japan that is non-Western but equally un-Asian remains an underlying theme. And Cool Japan as a government's attempt at re-imagining Japanese uniqueness is a project in search of a definition; and it is this lack of definition which provides a fertile platform upon which the traditional representations of Japanese uniqueness assume a default position. If the Japanese government considers the pursuit of public diplomacy as a national interest, then we 
need to reveal the inherent disconnect within Cool Japan between the government and domestic stakeholders.

\section{Cool Japan: Commoditizing National Identity}

The language of Cool Japan first entered the official lexicon in the early $21^{\text {st }}$ century. In 2002, Douglas McGray praised Japan's 'Gross National Cool', suggesting that its soft and cultural powers held tremendous potential. For McGray (2002, p. 46), Japan's coolness derived from what the consumers of Japanese products felt about Japan, arguing that 'Japanese Cool', with its international-mainly Asian-appeal was tantamount to an export of Japan's soft power, as well as the manifestation of 'Japan's global cultural influence' (McGray, 2002, p. 47). For him, '[w] hat made Japan a superpower, more than just a wealthy country, was the way its great firms staked claims to a collective intellectual high ground that left competitors, even in the United States, scrambling to reverse-engineer Japanese success' (McGray, 2002, p. 47). McGray (2002, p. 48) went on to suggest that,

If Japanese government sorts out its economic mess and military angst, and if younger Japanese become secure in asserting their own values and traditions, Tokyo can regain the role it briefly assumed at the turn of the $19^{\text {th }}$ century, when it simultaneously sought to engage the West and to become a military and cultural power on its own terms. 
In reiterating his assertion that what counts is the image of coolness rather than cultural authenticity, McGray (2002, p. 50) suggested that 'Hello Kitty is Western, so she will sell in Japan. She is Japanese, so she will sell in the West'. He urged Japan to pursue soft power through nation branding, stimulating the economy by reforming Japan's rigid social hierarchy and empowering young entrepreneurs (McGray, 2002, p. $51)$.

Popular culture defines Cool Japan, capitalizing on the international popularity of Japanese anime and manga. The Japanese government realized the soft power potential of these products, and has been hosting Japan International Contents Festa, or 'CoFesta', since 2007 (Tourism Agency, 2010, p. 88). Just as Japanese traditional arts and crafts have been promoted as a tool for public diplomacy, the 2011 Tourism White Paper considered the role of popular culture as fostering deeper understanding (rikai wo fukame) of Japanese culture and society, thereby enhancing Japan's international legitimacy and trustworthiness (Tourism Agency, 2011, p. 103). But the aftermath of 3/11 damaged Japan brand; and it became an imperative for the Japanese government to repair the country's reputation by reassuring visitors that Japan remained safe (Tourism Agency 2011, 88-89), with the Tourism Agency (2012, p. 90) identifying regaining of trust (shinrai kaifuku) as a priority. Simultaneously, the destruction meant reconstruction, and traditional crafts from affected regions were identified as vital components of Japan brand in helping to revitalize the regional economy (Tourism Agency, 2012, p. 88).

Cool Japan itself became more prominent since 2010, when the Ministry of Economy, Trade, and Industry (METI) (2011b) organized a series of meetings of eminent people to discuss how to package the concept. The catchphrase, Cool Japan, itself seems to have appeared all of a sudden, led primarily by METI and its advisors. 
According to MOFA (2011, p. 214), Cool Japan constituted an integral part of the economic growth strategy, and the Cool Japan Initiative considered promoting contents industry, design, and cuisine to turn Japan into an attractive destination for inbound tourists (MOFA, 2012, p. 236). The proposal issued by the METI PublicPrivate Eminent Persons Conference in May 2011 laid out the Cool Japan strategy. The Proposal identified addressing safety concerns following 3/11 as a priority; but the target was recast from reconstruction (fukugen) to evolution (shinka) in Japanese fiscal structure (METI 2011a, p. 1). The Proposal suggested that Japan has an inherent 'value' (kachi) that can be distilled down to core cultural attributes such as 'spirituality' (seishinsei), ‘agreeability' (kyōkanryoku), 'acceptability’ (juyōryoku), and 'sustainability' (jizoku-ryoku). It also claimed that Japan is 'a mountain of treasures' (takara no yama) that contained pop culture, food, design, architecture, and contemporary art, along with traditional arts, including regional specialities. The task for the nation was identified as commodifying these values to leverage the economy (METI, 2011a, pp. 2-3).

The working groups established during the Democratic Party of Japan (DPJ) government and retained by the Abe administration grappled with the definition of Cool Japan. What emerges from these meetings is that Cool Japan remains a concept in search of a definition: it is a convenient catchphrase, but the label seems to have assumed a life of its own without a clear definition. Ōshima Akihiro of METI told a meeting of Intellectual Property Strategy working group in October 2010 that "“Cool Japan" refers to an amalgam of Japanese fashion, anime, design, interior, cuisine, and tourism and other cultural industries [bunka sangyō]. They are extremely popular abroad, and we consider them to constitute one pillar of Japan's strategic industries' (Kantei, 2010b). At the same meeting, Kadokawa Tusuguhiko of Kadokawa 
publishing company echoed this sentiment, quoting from the film, Social Network, which mentioned that 'Japanese culture is cool' (Kantei, 2010b). The preference for style over substance continued. At a meeting of Research Committee for Contents Business in February 2011, chairman Nakamura Ichiya argued that Cool Japan is 'not just about contents, the Japanese power of expression, and the power of communication, it is also about manufacturing skills [monozukuri no chikara toka gijutsu toka]' (Kantei, 2011e), and in the same meeting, a business man, Kutaragi Ken, stated that, "I consider "Cool Japan" to include not just $20^{\text {th }}$ century goods and services that you can copy, but also those that cannot be copied, such as user experience [yūzā taiken]' (Kantei, 2011e).

From the government's perspective, the vagueness remains convenient in framing Cool Japan as an economic programme. At a February 2011 meeting of Contents Business research group, Nara Toshiya of the Cabinet Office defined Cool Japan as a 'driving force for economic growth [keizai-seichō no gendōryoku]' by encouraging tourism and economic revitalization, adding that, 'we are also hopeful that it will impact on the image of our country, as well as on other industries' (Kantei, 2011d). An official from METI, Watanabe Tetsuya, reiterated similar vagueness at a January 2012 meeting of the Contents Business research group, when he stated that, 'at first, Cool Japan referred merely to contents, but people are now considering traditional crafts as Cool Japan, as well as manufacturing industries rooted to the regions as comprising Cool Japan' (Kantei, 2012e). This was echoed in the same meeting by Andō Toshinori of the Cabinet Office, who suggested that 'Cool Japan used to be about anime, manga, and contents, but we are trying to expand our wings [wingu wo hirogete] and include fashion, cuisine and tourism; and hi-tech might also 
be considered Cool Japan' (Kantei, 2012e). Yet, this vagueness solicited questions about its definition. As early as March 2012, Kutaragi, argued that,

I don't quite understand what is meant by 'Cool Japan as incorporating attractiveness of Japanese culture and its platform'. I would like to think of it as 'the attractiveness of Japanese culture that we can appeal to the world as Cool Japan itself' (Kantei, 2012c).

It seems that the vagueness culminated in more attributes being grafted onto the catchphrase to maximize economic potential.

With the return to power of Prime Minister Abe Shinzō in December 2012, Cool Japan became a convenient vehicle for his nationalist programme. Simultaneously, its economic component dovetailed with the so-called 'Abenomics' in which Abe hoped to reflate the economy, with Cool Japan constituting an integral part of the government's programme. Abe's beliefs seem amenable to what Cool Japan seeks to accomplish. Writing in his 2013 book, Towards a New Country (Atarashii kuni-e) - a revized edition of the 2006 publication, Towards a Beautiful Country (Utsukushii kuni-e)—Abe mentions that high-tech and innovation are central to his vision of Japan's future. While not mentioning Cool Japan by name, he emphasizes the centrality of state $(k o k k a)$ in his thinking, arguing that the good reputation of the state benefits the people because that is how the Japanese are respected around the world (Abe, 2013, pp. 66-69). Abe (2013,pp. 161-62) notes that his ambition is for Japan to become a country of choice for skilled global talent. He highlights the importance of 'innovation as a key to growth strategy', arguing that Japan needs to 'utilize its unique human resourcefulness, technological-, and cultural 
power to bring about a breakthrough in solving "new challenges" [atarashii kadai] via new technology, ideas, and creative solutions' (Abe, 2013, p. 242). In a 2014 article, Abe (2014, p. 95) again stresses that 'Japan is recognized as a country full of worldclass human resource and businesses', and that the 'time has finally come for Japanese [regional producers] to move beyond the domestic market and jump into the world' (Abe, 2014, p. 102). In another article published in 2015, Abe (2015, p. 100) points out that Japan needs to be at the forefront of liberal trading regime, as this is the only way through which Japan's unique regional brands such as Matsuzaka beef, Yübari melon, and Uonuma koshihikari rice can be promoted worldwide. Hence, in Abe, Cool Japan has found an avid supporter; and for Abe, Cool Japan is a useful hanger for his political and economic revitalization programme and a means for enhancing national dignity. This happy coincidence seems to explain why Cool Japan remained resilient despite the problems reaching out to the stakeholders.

In order to implement the Cool Japan Initiative, 'Cool Japan Fund' was established by METI in May 2013 in an effort at 'expanding business opportunities that realizes Cool Japan'. And in the December 2014 meeting of Verification, Appraisal, and Planning committee, an activist promoting copyright issues, Seo Taichi, pointed out that, 'it is crucial that we sell Japanese industry using contents as an advance contingent [sempei], rather than selling the contents themselves' (Kantei, 2014). The Fund identified Cool Japan as consisting of Japanese values enshrined within products such as automobiles, white goods, electronics, and other traditional industries; and it sought to add value to a further set of items such as clothes, food, 'the ways of living' (ishokujū ), as well as the contents industry, along with 'Japanese tradition and lifestyle' (METI, 2015, p. 1). These items were to be promoted to foreign stakeholders through the hosting of 'Japan Days' at international gatherings 
(METI, 2015, p. 7), and to facilitate 'business matching' whereby Japanese business organizations were able to meet their international counterparts (METI, 2015, p. 13). For Abe, Cool Japan remains a crucial tool in addressing Japan's population decline, reiterating in March 2018 the importance of attracting Cool Japan human resources (kūru Japan jinzai) globally as a vital source for sustaining Japan's soft power (Kantei, 2018).

From the official narratives, we can see that Cool Japan comprizes two main elements: (1) promoting a Japan brand that is established on the reputation of Japanese products, particularly the contents industry; and (2) using Japan's international appeal in an effort at leveraging post-3/11 reconstruction efforts, and to prepare for the gradual- and steady population decline that challenges Japan's longerterm economic performance. Together, it meant commoditizing Japanese identity, enlisting anything that seems to represent Japaneseness. Simultaneously, though, the fiscal necessity compelled the Japanese government to identify an ever-wider range of products, effectively diluting the message being sent out to both international, as well as domestic, audience.

\section{Cool Japan: The Pitfalls of Government-led Identity Entrepreneurship}

While Cool Japan might be a convenient catchphrase, it suffers from vagueness. The government considers Cool Japan to be a viable tool for public diplomacy promoting Japanese products to international audience and to attract inbound tourists in an attempt at reflating the economy. As such, definition is less important than the image of Japan that is being sold to consumers worldwide. And it is this vagueness which 
reinforces the familiar historical designation of Japan as a visual puzzle within which modernity cohabitates with tradition, as we saw back in Tokyo 1940 and 1964 Olympics bids. The Eminent Persons' Proposal resonates with the residues of prewar identity narratives, when it makes note of the 'high quality of Japanese spirituality [Nippon-jin no seishinsei no takasa]' highlighting Japanese diligence and resilience following 3/11 (METI, 2011a, p. 1). Furthermore, the Proposal stressed the juxtaposition of Eastern- and Western values inherent in Japanese culture that enabled Japanese producers to establish a 'Japanese dual-standard [Nihon-teki duaru standādo-sei]' (METI, 2011a, p. 4), as a way to turn 'Japan' into a viable 'story' (monogatari) (METI, 2011a, p. 5).

Indeed, vagueness defines Cool Japan. According to the Proposal, 'the power of "Japan brand" entails an establishment of uniquely Japanese key words, and the relationship between a noun and verb, along with the identification of a locus [ba]' (METI, 2011a, p. 6). The working groups established by the government discussed what actually is meant by Cool Japan, with group members wondering aloud what the essence behind the catchphrase might be. In a February 2011 meeting of Contents Business research committee, one member, Kawakami Ryōsei, claimed that Cool Japan has become a 'slogan', but 'one wonders what on earth is meant by it [somo somo nan nanoka]', reiterating the need to 'clarify what is meant by Cool Japan, as well as Japan's strengths' (Kantei, 2011e). In the same meeting, another member, Satō Naoki, also pointed out that 'we need to define what is meant by Cool Japan', to which Kondō Kenji of Cabinet Office admitted that 'it is a difficult problem [dōshite iika muzukashii mondai desu]' (Kantei, 2011e). In a later meeting of the same working group in February 2011, another official, Nara Toshiya, argued that it is important to proactively unearth and create through trial and error, then establish 
deductively [en-eki tekini] and through expanding the frontiers', to which Kawakami responded, 'I feel that Cool Japan remains the weakest of all' (Kantei, 2011d).

Further discussions revealed the fuzziness of Cool Japan. In the March 2011 meeting of the Contents Business research committee, Kondō suggested that "what is “cool" depends on what the people think' (Kantei, 2011c). This lack of a clear definition became a point of contention in an April 2011 meeting of Contents Business research committee. Here, Kadokawa argued that 'Cool Japan as a key word has taken on a life of its own. To put it bluntly, it sounds as if it is designed to make [Cool Japan] look abstract', adding that 'Cool Japan as a word [kotoba] takes on a life of its own without us knowing what it means, and while its definition remains vague [teigi no ayafuya] (Kantei, 2011b). This sentiment was repeated in the December 2012 meeting of Contents Business research committee, when Niiyama Kenji of the national broadcaster, NHK, stated that 'I have always wondered what Cool Japan meant', trying to figure out 'what is it about Cool Japan that we want to sell to the world' (Kantei, 2012a). To this, an actor, Bessho Tetsuya, asked: 'what on earth is Cool Japan [küru Japan towa nanzoya]? ... The people are not aware of the actual plans' (Kantei, 2012a). Even the participants of working groups seem at a loss to define what is meant by it.

This is the challenge of this government-led nation branding projectsomething that was criticized by a Japanese entertainer, Gackt, in his blog. Gackt felt that METI was losing focus, asking in 2015, 'I wonder if anyone in Japan actually understands what Cool Japan does?' (RocketNews24, 2015). He was sceptical of the utility of nation branding exercise, claiming that, 
The Japanese government made a new attempt at this in the name of Cool Japan, but while they have set up a huge budget for it, they have no idea where that money should go. It's no exaggeration to say it has fallen into a downward spiral of wasted tax money flowing into little known companies (RocketNews24, 2015).

He added that,

But the Cool Japan budget is still floating in the air. Who the hell is this budget for? I wonder if anyone living in Japan actually understands what Cool Japan does. I wonder what Cool Japan does. How many people can clearly answer that question? (RocketNews24, 2015)

Gackt's frustration represents the challenge of Cool Japan Initiative: the government's struggle to enlist domestic stakeholders in the pursuit of public diplomacy.

It is this vagueness which lends itself to the relevance of historical identity construction. The tendency towards essentialism is understandable when no discernible definition is provided, encouraging officials and advisors to define Cool Japan as something that is uniquely Japanese, distinguishing Japaneseness from things that are considered Western or Asian, however construed. In the absence of a clear definition, the temptation is to suggest that Japan is unique because it is not Asian nor Western. And it is here that we can witness the residues of historical identity construction helping to put Cool Japan into an ideational context. It is here that Cool Japan defaults to the familiar characteristics of Japanese identity representation. 


\section{Cool Japan and the Residues of Japanese Uniqueness Myth}

Cool Japan suffers from vagueness, as its two main components-identity representation and trade promotion - fail to fully integrate. On the one hand, there is recourse to the familiar image of Japan's tradition and hospitality. On the other hand, the success of manga and anime, along with Japan's track record on high-tech industries, provides a temptation to fuse the two dimensions in an effort at constructing an effective and coherent Japan brand. Furthermore, the top-down nature of the project makes public awareness challenging.

Yet, it is this vagueness and the diffuse identification of numerous, disparate, Japanese products as constituting Cool Japan that sustains the familiar narratives of Japanese identity. The conceptual void left by the Cool Japan project enables the idea of Japanese uniqueness to define this nation branding exercise. In the absence of a coherent image, the identity narratives inherent within Cool Japan reverts to constructing Japan into a locus of cohabitation between the East and West, of tradition and modernity, while simultaneously being an unrivalled unique entity. The familiar residues of Japan as a uniquely non-Western and un-Asian entity re-emerges, reconstructing a story of Japaneseness defined through a culture of unrivalled precision and warmth, of diligence and hospitality. Thus, contemporary signifiers of Japan brand sediment onto the familiar identity narratives, making it convenient for policy makers and stakeholders to upload anything that can be associated with an abstract idea of Japaneseness.

In promoting Cool Japan, commentators allude to Japan's unique cultural attributes as the main attraction. Yoshizaki Tatsuhiko (2007, p. 27) argues that, 'in 
order to increase the number of fans, we need a strategy for the Japanese and Japanese culture to promote Japan brand'. He suggests that Japan is imagined as diligent and honest, with the idea of "honest Japan" needing to be at the centre of advertizing strategy' (Yoshizaki, 2007, p. 29). In a similar vein, Watanabe Yasushi (2009, p. 15) invokes pacifism as Japan's unique attribute, pointing out that, in order to turn culture into a soft power, 'we need to establish a clear policy target [seisaku mokuhyō]', adding that, 'while not as spectacular [hanabanashii] as Hollywood films, Japan's pacifism and resilience should be adequate in formulating "another Cool Japan" [ $m \bar{o}$ hitostu no kūru Japan]'. To achieve this, Watanabe posits that 'leveraging Japan's postwar reconstruction and discussing democracy in promoting national unity in Iraq is meaningful from the perspective of cultural diplomacy [bunka gaikō]'. Furthermore, the idea of Japan as a hub for Asian culture and technology during the late- $19^{\text {th }}$ and early- $20^{\text {th }}$ centuries remains attractive, with commentators considering the possibility of Japan becoming an Asian hub for contents industry. Sakurai Takamasa (2009, p. 23) notes that anime conventions act as "crucial hubs for "anime cultural diplomacy" [anime bunka gaikō]', whereby 'once youths from all over the world realize that these anime were created in Japan, then Japan as a country almost assumes a father- or a mother-figure' for them. For Sakurai (2009, p. 25), 'appreciation of anime and manga enhances an appreciation for Japanese tradition and lifestyle, and eventually Japan itself'.

Along with the need to reinforce Japan's pacifist image, the idea of unique Japan amidst the East and West remains attractive for policy makers. The image of Japan that is capable of absorbing knowledge from the outside and then imparting it onto an economically disparate Asia persists in the official justification for Cool Japan. A former MOFA official and the Director of Cultural Agency, Kondō Seiichi, 
suggests that 'Cool Japan is an important programme to make [Japanese culture] more accessible' (Chīō kōron, 2005, p. 114). Invoking the history of Japan's interactions with the outside world, he argues that 'the Japanese have explored outside the country to absorb knowledge since the Meiji era, and they have returned to construct a wonderful state and society. Now, Japan must be able to attract youths and "inspire them"'- just as Japan inspired young Asians at the turn of the previous century (Chīo kōron, 2005, p. 115). Furthermore, emphasizing how distinct Asia is from the West, Kondō notes that, "due to differences in economic development, religion, and languages, a community akin to Europe will be difficult to forge in East Asia', making cultural exchanges even more crucial (Chūo kōron, 2005, pp. 116-17). He reiterated his belief that 'pop culture makes it accessible for foreigners to appreciate and familiarize themselves with Japan' (Kondō, 2010, p. 18), but also seems mindful of Cool Japan's lack of a clear focus, adding that, 'while Japanese arts and culture are laudable and approved by the international community, the Japanese themselves are not aware of this' (Kondō, 2010, p. 21).

Given that Cool Japan is a nation branding exercise, it is not surprising that the Japanese uniqueness is emphasized. Yet, the language of uniqueness resembling the 1964 Tokyo Olympics bid, let alone the prewar narratives, provides a glimpse of the residues of familiar identity narratives as forming the bedrock of contemporary identity construction. In the February 2011 meeting of the Contents Business research committee, Nara Toshiya of Cabinet Office stated that, 'everything about Japan seems to be considered as constituting Cool Japan. There are gaps in what the Japanese considered [to be Cool Japan] on the one hand, with what foreigners feel [to be cool]' (Kantei, 2011d). He added that, '[we think that] Japan's unique identity [koy $\bar{u}$ no aidentitī is seen as cool in the eyes of a person from foreign lands [ikokujin no me]', 
including 'the unique culture, tradition, or the unique obsession [dokutoku no kodawari]' (Kantei, 2011d). In the March 2011 meeting of the same research group, Nara reiterated that 'our country's unique culture and tradition, along with the unique obsession [kodawari] and politeness' are a source of Japan's global business opportunity (Kantei, 2011c). He then suggested that it is the attraction of 'Japan's unique identity [Nippon koyū no aidentitī] that should be leveraged' (Kantei, 2011c). A similar language of Japanese uniqueness was put forward by Seno-o Kenichirō of the Intellectual Property working group in December 2012. He hoped to promote Japanese intellectual property policy by emphasizing 'Japan as an extremely unique place [Nippon to iu kanari yunīku na tokoro]' (Kantei, 2012a).

Furthermore, the residues of dual Otherness are identifiable within the deliberation of official working groups as well. Here, we can catch a glimpse of a complex ideational relationship between Japan and Asia-indicating Japan's Asian affinity while wanting to be different from it. In a December 2010 meeting of the Contents Business working group. Nara outlined the intent behind Cool Japan to be Japan becoming the 'hub [kyoten]' for Asian creativity (Kantei, 2010a)—a sentiment he repeated in March 2011, when he suggested that 'Japan needs to become a creative hub where people and information from Asia and the wider world gather' (Kantei, 2011a). An actor, Bessho Tetsuya, went futher in the February 2011 Contents Business working group, when he felt that national strategy (kokka senryaku) should be ambitious enough for Japan to want to 'control [gyüjiru] all the information in Asia' and that Cool Japan needs to be framed as 'strengthening information national defence [jōhō kokubō suishin]' (Kantei, 2011d). And in the December 2013 meeting of the Verification, Evaluation, and Planning meeting, Seo Taichi pointed out that the contents industry possesses not only economic, but also diplomatic, policy 
implications within the Asian region. He added that, 'while the Europeans and Americans are preoccupied with making money', it is important to respect 'the unique Asian production system, and to nurture common Asian cultural market' (Kantei, 2013). Seo stressed that 'it is important to locate Cool Japan within the context of a larger Asian Strategy' (Kantei, 2013).

Simultaneously, the residues of Japan that is distinct from the West can be seen as well. Satonaka Machiko, a cartoonist and member of the Contents Business research group, observed in March 2012 that she felt the discussions revolved around a presumption that there is 'the need to reassert Otherness [mazu aite ariki]' to 'resist some form of Western things' (Kantei, 2012d). A subtle reference to the notion that Japanese culture is characteristically more refined than the West is made by Uemrua Yachio in the April 2012 meeting of the Contents Business group. Uemura focused on the quality of Japanese books, claiming that "the layout of Japanese books is "strong" [tsuyoi]. Perhaps it is because the Japanese language is phono-grammatic, distinct from the Western alphabet.... When I show Japanese books, the foreigners think they are seeing magazines' (Kantei, 2012b).

Japan's relationship with Asia and the West, as witnessed through Cool Japan deliberations, is subtler than the earlier versions of nation branding exercise. Yet, it also remains the case that the very act of defining Japaneseness still requires the altercasting of Asia and the West as entities against which Japan is understood. While delineating Asia and the West derives from practical concerns-as Japan's export markets - it is also the case that the construction of Japanese Self is predicated on the familiar dual Otherness.

Simultaneously, though, the political implications of identity narratives such as Cool Japan is that this is a case of a failed identity entrepreneurship. Abe's 
nationalism seems to account for its resilience, since his nationalism dovetails nicely with the identity narratives inherent in Cool Japan. Abe's nationalism is not just a tool for sustaining his conservative support base, but 'resonates with Abe's nationalistic track record' (Nagy, 2014, p. 12) and 'appears to be sincerely held' (Envall, 2018, p. 18). Cool Japan is a case study in which the state engages in identity entrepreneurship but fails to convince the stakeholders. But, particularly given Abe's pragmatism, it remains likely that the familiar identity narratives will re-emerge when the government believes that the promotion of Japaneseness will help to promote Japanese exports, attract inward foreign direct investment, and revitalize the stagnant economy. Ultimately, Cool Japan remains a convenient policy tool at Japanese government's disposal, in which case the veracity of claims to Japaneseness in Cool Japan identity narratives is not a government priority. As long as soft power is considered a viable foreign policy option, states will consider packaging national identity narratives as a facet of their national interests. The project of nation branding in Japan reveals that what ultimately matters are economic benefits, and as a result, Japanese national identity defined through Cool Japan sediment on top of the preestablished identity narratives shared by the generations of policy elites. In short, Cool Japan is a $21^{\text {st }}$ century reinforcement by the government of a longstanding identity representation.

\section{Conclusion}

As a government undertaking, Cool Japan Initiative remains a top-down project: it is driven by policy elites concerned with promoting exports and inbound tourism, along 
with government-appointed advisers tasked with attaching labels to a disparate set of 'things' which can be construed as quintessentially 'Japanese'. Some Japanese products lend themselves well to the image of Japaneseness, such as Japanese cuisine and Japanese cultural tradition. Others require more intricate association with being Japanese: manga and anime, as well as androids that can run and dance, need emphasizing that they are Japanese products. This is particularly the case when the focus shifts to intangibles such as hospitality and services. The things that can be construed as Japanese remain varied and vague; and Cool Japan suffers from a lack of clear focus.

It is the vagueness of Cool Japan that lends itself to the residues of traditional identity narratives constituting a default position. Despite pacifism being utilized to distinguish postwar Japan from its prewar version, it is striking to witness the residues of an idea that Japan is simultaneously non-Western and un-Asian, and therefore essentially a unique entity, retains its function in the $21^{\text {st }}$ century. The form of identity construction that was witnessed in the late $-19^{\text {th }}$ and early- $20^{\text {th }}$ centuries remains valid, providing a platform for Cool Japan which otherwise remains vague. In other words, the myth of Japanese uniqueness still constitutes the core identity narrative that underpins Cool Japan. This is particularly the case, given the challenges of portraying a coherent Japan brand that is driven primarily by the economic imperatives of postbubble and post-3/11 Japan. Cool Japan's quest for whatever might be meant by Japaneseness is sedimenting onto an existing layer of historically constructed Japanese identity narratives, neutralizing the newness of Cool Japan as a project. To be sure, pacifism and consumer culture today provide the main driver for identifying Japaneseness rather than the racialist and militaristic antagonisms of the prewar 
decades. But it is equally the case that there remains a subtle undercurrent portraying Japan as a uniquely non-Western and un-Asian cultural entity.

Such difficulties make it likely that the policy elites and other stakeholders rely on existing signifiers of Japaneseness to produce a coherent identity package. The core message behind the official story of Japan brand is that Japan, as a unique cultural entity, is able to contribute an unparalleled consumer experience that is unavailable elsewhere. However vague it might be, Cool Japan remains a vehicle for the Japanese government to pursue its national interests, via public diplomacy. Hence, the priority for Japanese officials is to simply ignore the vagueness in favour of pursuing Cool Japan's purported economic benefits. And within such a process, Cool Japan represents a further sedimentation of $21^{\text {st }}$ century signifiers to the resilient layer of the myth of Japanese uniqueness.

\section{Reference}

Abe S. (2015, December). Abenomikusu no seihi wo tou 'ichioku sō-katsuyō' waga shin-i [Appraising Abenomics: my determination with mobilising 100 million]. Bungei shunjū, 94-103.

Abe S. (2014, September). Abe Shinzō Abenomikusu dai-2 shō kidō sengen [Abe Shinzō, declaraing the second chapter of Abenomics]. Bungei shunjū, 94-105.

Abe S. (2013). Atarashii kuni-e [Towards a new country]. Tokyo: Bunshun bunko. 
Abel, J. (2011). Can Cool Japan save Post-Disaster Japan? On the Possibilities and Impossibilities of a Cool Japanology. International Journal of Japanese Sociology 20 (1), 59-72.

Anholt, S. (2011). Beyond the Nation Brand: The Role of Image and Identity in International Relations. Exchange: The Journal of Public Diplomacy, 2 (1), 6-12.

Anholt, S. 2007. Competitive Identity: The New Brand Management for Nations, Cities, and Regions. Basingstoke: Palgrave Macmillan.

Banno J. (2013). Kindai Nihon to Ajia [Modern Japan and Asia]. Tokyo: Chikuma gakujutsu bunko.

Brienza, C. (2014). Did Manga Conquer America? Implications for the Cultural Policy of 'Cool Japan'. International Journal of Cultural Policy, 20 (4), 383-98.

Chūo kōron. (2005, October). Sekai ni 'Nihon no anime sedai' wo sodateyo [Let's nurture 'Japanese anime generation' across the world]. Chūo kōron, 107-17.

Collins, S. (2007). The 1940 Olympics: Imperial Commemoration and Diplomacy. The International Journal of the History of Sport, 24(8), 977-1002. . (2006). Conflicts of 1930s Japanese Olympic Diplomacy in Universalizing the Olympic Movement. The Journal of the History of Sport, 23(7), 1128-51. 
Cull, N. J. (2008). Public Diplomacy: Taxonomies and Histories. Annals 616(1), 3154.

Daliot-Bul, M. (2009). Japan Brand Strategy: The Taming of 'Cool Japan' and the Challenges of Cultural Planning in a Postmodern Age. Social Science Japan Journal, $12(2), 247-66$.

Dinnie, K. (2016). Nation Branding: Concepts, Issues, Practice (2nd ed.). London: Routledge.

Envall, H.D.P. (2018). 'The “Abe Doctrine”: Japan's New Regional Realism', International Relations of the Asia-Pacific. Online Article First: 1-29.

Fauchart, E., and Gruber, M. (2011). 'Darwinians, Communitarians, and Missionaries: The Role of Founder Identity in Entrepreneurship', The Academy of Management Journal, 54(5): 935-57.

Haslam, S. A., and Reicher, S. 2007. 'Identity Entrepreneruship and the Consequences of Identity Failure: The Dynamics of Leadership in the BBC Prison Study', Social Psychology Quarterly, 70(2): 125-47.

Hirakwa S. (1998). Japan's Turn to the West (translated by Bob Tadashi Wakabayashi). In Bob Tadashi Wakabayashi (Ed.), Modern Japanese Thought (chapter 2). Cambridge: Cambridge University Press. 
Horne, J., and Manzenreiter, W. (2012). Olympic Tales from the East: Tokyo 1964, Seoul 1998 and Beijing 2008. In Helen Jefferson Lenskyi and Stephen Wagg (Eds.), The Palgrave Handbook of Olympic Studies (chapter 7). London: Palgrave.

Ikei M. (2012). Katarare nakatta sengo Nippon gaikō [The untold postwar Japanese diplomacy]. Tokyo: Keiō gijuku daigaku shuppankai.

Iriye A. (1966). Nihon no gaikō [Japan's diplomacy]. Tokyo: Chūkō shinsho.

Iwabuchi, K. (2015). Pop-culture Diplomacy in Japan: Soft Power, Nation Branding, and the Question of 'International Cultural Exchange'. International Journal of Cultural Policy, 21(4), 419-32.

Kantei (2018, March 26). Kokka senryaku tokubetsu kuiki shimon kaigi [The national strategic special zone advisory meeting]. Retrieved from: https://www.kantei.go.jp/jp/98_abe/actions/201803/26senryaku_tokku.html. Accessed on 18 February 2018.

Kantei (2014, December 9). Kenshō, hyōka, kikaku iinkai (dai 5-kai) gijiroku [The minutes of validation, evaluation, and planning committee $5^{\text {th }}$ meeting]. Reterieved from https://www.kantei.go.jp/jp/singi/titeki2/tyousakai/kensho_hyoka_kikaku/2015/ dai5/gijiroku.html. Accessed on 2 May 2018.

Kantei (2013, December 12). Kenshō, hyōka, kikaku iin-kai (dai 5-kai) gijiroku [The minutes of validation, evaluation, and planning committee $5^{\text {th }}$ meeting]. Retrieved 
from https://www.kantei.go.jp/jp/singi/titeki2/tyousakai/kensho_hyoka_kikaku/dai5/ gijiroku.html. Accessed on 2 May 2018.

Kantei (2012a, December 25). Kontentsu kyōka senmon chōsa-kai (dai 1-kai) gijiroku [The minutes of Contents Business Research Group $1^{\text {st }}$ meeting]. Retrieved from https://www.kantei.go.jp/jp/singi/titeki2/tyousakai/contents_kyouka/2013/dai1/ gijiroku.html. Accessed on 2 May 2018.

Kantei (2012b, April 23). Kontentsu kyōka senmon chōsakai (dai 9-kai) gijiroku [The minutes of the Contents Business Research Group $9^{\text {th }}$ meeting]. Retrieved from https://www.kantei.go.jp/jp/singi/titeki2/tyousakai/contents_kyouka/2012/dai9/gijirok u.html. Accessed on 2 May 2018.

Kantei (2012c, March 13). Kontentsu kyōka senmon chōsa-kai (dai 8-kai) gijiroku [The minutes of the Contents Business Research Group $8^{\text {th }}$ meeting]. Retrieved from https://www.kantei.go.jp/jp/singi/titeki2/tyousakai/contents_kyouka/2012/dai8/gijirok u.html. Accessed on 2 May 2018.

Kantei (2012d, March 7) Kontentsu kyōka senmon chōsakai (dai 7-kai) gijiroku [The minutes of the Contents Business Research Group $7^{\text {th }}$ meeting]. Retrieved from https://www.kantei.go.jp/jp/singi/titeki2/tyousakai/contents_kyouka/2012/dai7/gijirok u.html. Accessed on 2 May 2018.

Kantei. (2012e, January 18). Kontentsu kyōka senmon chōsa-kai (dai 4-kai) gijiroku [The minutes of the Contents Business Research Group $4^{\text {th }}$ meeting]. Retrieved from 
https://www.kantei.go.jp/jp/singi/titeki2/tyousakai/contents_kyouka/2012/dai4/gijirok u.html. Accessed on 2 May 2018.

Kantei (2011a, May 13). Kontentsu kyōka senmom chōsa-kai (dai 10-kai) gijiroku [The minutes of the Contents Business Research Group $10^{\text {th }}$ meeting]. Retrieved from https://www.kantei.go.jp/jp/singi/titeki2/tyousakai/contents_kyouka/2011/dai10/gijiro ku.html. Accesed on 2 May 2018.

Kantei (2011b, April 26). Kontentsu kyōka senmon chōsa-kai (dai 9-kai) gijiroku [The minutes of the Contents Business Research Group $9^{\text {th }}$ meeting]. Retrieved from https://www.kantei.go.jp/jp/singi/titeki2/tyousakai/contents_kyouka/2011/dai9/gijirok u.html. Accessed on 2 May 2018.

Kantei (2011c, March 10). Kontentsu kyōka senmon chōsa-kai (dai 8-kai) gijiroku [The minutes of the Contents Business Research Group $8^{\text {th }}$ meeting]. Retrieved from https://www.kantei.go.jp/jp/singi/titeki2/tyousakai/contents_kyouka/2011/dai8/gijirok u.html. Accessed on 2 May 2018.

Kantei (2011d, February 25). Kontentsu kyōka senmon chōsa-kai (dai 7-kai) gijiroku [The minutes of the Contents Business Research Group $7^{\text {th }}$ meeting]. Retrieved from https://www.kantei.go.jp/jp/singi/titeki2/tyousakai/contents_kyouka/2011/dai7/ gijiroku.html. Accessed on 2 May 2018.

Kantei (2011e, February 10). Kontentsu kyōka senmon chosa-kai (dai 6-kai) gijiroku [The minutes of the Contents Business Research Group $6^{\text {th }}$ meeting]. Retrieved from 
https://www.kantei.go.jp/jp/singi/titeki2/tyousakai/contents_kyouka/2011/dai6/ gijiroku.html. Accessed on 2 May 2018.

Kantei (2010a, December 20). Kontentsu kyōka senmom chōsa-kai (dai 4 kai) gijiroku [The minutes of the Contents Business Research Group $4^{\text {th }}$ meeting]. Retrieved from https://www.kantei.go.jp/jp/singi/titeki2/tyousakai/contents_kyouka/2011/dai4/ gijiroku.html. Accessed 2 May 2018.

Kantei (2010b, October 26). Chiteki-zaisan senryaku honbu kaigō gijiroku [The minutes of Intellectual Property Strategy Group]. Retrieved from https://www.kantei. go.jp/jp/singi/titeki2/101026/gijiroku.html. Accessed on 2 May 2018.

Kondō S. (2010, November). Bunka no chikara de Nippon to gaikō wo motto genki ni shiyō [Let's revitalize Japan and diplomacy through cultural power]. Gaikō, Vol. 3, $16-23$.

Lee K.- T. (2015). Nihon ni okeru 'atarashii' paburikku dipuromashī no chōsen to sono genkai [Challenges and limits of new public diplomacy in Japan]. Kokusai Nihon kenkyū (Online), Vol. 7, 153-65. Retrieved from http://japan.tsukuba.ac.jp/ research/. Accessed on 12 September 2017.

Maruyama M. (1961). Nippon no shisō [Japanese thought]. Tokyo: Iwanami shinsho.

McGray, D. (2002, May/June). Japan's Gross National Cool. Foreign Policy, 44-54. 
METI (2015). Kūru Japan seisaku ni tsuite [On Cool Japan Initiative]. Tokyo: METI.

METI (2011a). Atarashii Nippon no sōzō: 'bunka to sangyō' 'Nippon to kaigai' wo tsunagu tame $n i$ [Creating New Japan: connecting culture and industry, as well as Japan and overseas]. Tokyo: METI.

METI (2011b, May 12). Küru Japan kan-min yūshikisha kaigi teigen no torimatome ni tsuite [On the Cool Japan eminent persons committee report]. Tokyo: METI.

Mikami T. (2007). Paburikku dipromashī kenkyū no shatei [The direction of public diplomacy debate]. Shūdō hōgaku, 29(2), 1-22.

MOFA (2012). Gaikō seisho 2012 [Diplomatic bluebook 2012]. Tokyo: MOFA.

MOFA (2011). Gaikō seisho 2011 [Diplomatic bluebook 2011]. Tokyo: MOFA.

Mōri, Y. (2011). The Pitfall Facing the Cool Japan Project: The Transnational Development of the Anime Industry under the Condition of Post-Fordism. International Journal of Japanese Sociology, 20 (1), 30-42.

Nagasawa A. (2011). 'Kankō rikkoku' ni okeru kōkyōsei to paburikku dipuromashī no mondai [The problem of public diplomacy for tourist state and its public utility]. Kokusai kenkyū ronsō, 24(2), 105-118. 
Nagy, S. R. 2014. 'Nationalism, Domestic Politics, and the Japan Economic Rejuvenation', East Asia, 31(5): 5-21.

Nye, J. S. Jr. (2008). Public Diplomacy and Soft Power. Annals, 616(1), 94-109.

Okamoto K. (Ed.) (1998). Kindai Nippon no Ajia-kan [Asian perspectives in modern Japan]. Kyoto: Minerva.

RocketNews24 (2015, June 6). Gackt lashes out at Cool Japan: 'Almost no results of Japanese culture exported overseas'. Japan Today. Retrieved from https://www.japan today.com/smartphone/view/entertainment/gackt-lashes-out-at-cool-japan-almostno-results-of-japanese-culture-exported-overseas. Accessed on 10 November 2016.

Sakurai T. (2009, February). Anime wa chichi-oya ya haha-oya no yōna sonzai desu: sekai ni hirogaru bunka gaikō rūtsu no kanōsei [Anime is like a father and a mother: the possibilities of spreading the roots of cultural diplomacy]. Gaiko Forum, 22-25.

Sevin, E. (2015). Pathways of Connection: An Analytical Approach to The impacts of Public Diplomacy. Public Relations Review, 41(4), 562-68.

Taniguchi G. (1997). Hinomaru to orinpikku [Hinomaru and the Olympics]. Tokyo: Bungei shunjū.

TOCOG (2013). Rikkōho fairu [Candidature file], Vol. 1. Tokyo: TOCOG. 
Tourism Agency (2013). Heisei 25-nen ban kankō hakusho [Heisei 25 edition of Tourism White Paper]. Tokyo: Tourism Agency.

Tourism Agency. 2012. Heisei 24-nen ban kankō hakusho [Heisei 24 edition of Tourism White Paper]. Tokyo: Tourism Agency.

Tourism Agency. 2011. Heisei 23-nen ban kankō hakusho [Heisei 23 edition of Tourism White Paper]. Tokyo: Tourism Agency.

Tourism Agency. 2010. Heisei 22-nen ban kankō hakusho [Heisei 22 edition of Tourism White Paper]. Tokyo: Tourism Agency.

Valaskivi, K. (2013). A Brand New Future? Cool Japan and the Social Imaginary of the Branded Nation. Japan Forum, 25 (4), 485-504.

Watanabe H. (2001). Nihon no paburikku dipuromashī: japonizumu kara neojaponizumu e [Japanese public diplomacy: from Japonism to neo-Japonism]. Hōgaku kenkyū, 84(1), 153-74.

Watanabe Y. (2009, July). Nippon rashisa towa nanika: aidentitī to bunka gaikō [What is Japaneseness? Identity and cultural diplomacy]. Gaikō Forum, 12-17.

White, C., and Radic, D. (2014). Comparative Public Diplomacy: Message Strategies of Countries in Transition. Public Relations Review, 40(4), 459-65. 
Whitebrook, M. 2001. Identity, Narrative and Politics. London: Routledge.

Yamamuro S. (2001). Shisō kadai to shite no Ajia [Asia as a philosophical agenda]. Tokyo: Iwanami shoten.

Yoshida S. (1995). Nippon gaikō no ayundekita michi [The history of Japanese diplomacy]. In Kitaoka Shinichi (Ed.), Sengo Nippon gaikōron-shu (pp. 99-113). Tokyo: Chūō kōron.

Yoshimoto H. (2013). Paburikku dipuromashī no riron-teki wakugumi kōchiku ni mukete [Towards a theoretical framework for public diplomacy]. Yamaguchi kenritsudaigaku gakujutsu jōhō, No. 6, 29-38.

Yoshizaki T. (2007, February) Shizukana shūsai Nippon: senryaku-teki na paburikku dipuromashī yo susume [Japan as a quiet genius: towards a strategic public diplomacy]. Gaiko Forum, 26-29. 